\title{
Phytochemical composition and antimicrobial activities of the essential oils and organic extracts from pelargonium graveolens growing in Tunisia
}

Anis Ben Hsouna ${ }^{1,2}$ and Naceur Hamdi ${ }^{1,3^{*}}$

\begin{abstract}
Background: Pelargonium graveolens (P. graveolens) L. is an aromatic and medicinal plant belonging to the geraniacea family.

Results: The chemical compositions of the essential oil as well as the in vitro antimicrobial activities were investigated. The GC-MS analysis of the essential oil revealed 42 compounds. Linallol L, Citronellol, Geraniol, 6-Octen-1-ol, 3,7-dimethyl, formate and Selinene were identified as the major components. The tested oil and organic extracts exhibited a promising antimicrobial effect against a panel of microorganisms with diameter inhibition zones ranging from 12 to $34 \mathrm{~mm}$ and $\mathrm{MIC}_{\mathrm{s}}$ values from 0.039 to $10 \mathrm{mg} / \mathrm{ml}$. The investigation of the phenolic content showed that $\mathrm{EtOAc}, \mathrm{MeOH}$ and water extracts had the highest phenolic contents.

Conclusion: Overall, results presented here suggest that the essential oil and organic extracts of $P$. graveolens possesses antimicrobial and properties, and is therefore a potential source of active ingredients for food and pharmaceutical industry.
\end{abstract}

Keywords: P. graveolens, Antimicrobial activity, Essential oils, Organic extracts, GC/MS

\section{Background}

In recent years, there has been considerable interest in the search for antioxidants and antimicrobial compounds from natural sources to control human and plant diseases [1]. Natural antioxidants inhibit the oxidative damage of food products and may prevent inflammatory conditions [2], ageing and neurodegenerative disease [3]. The market constantly addresses its attention to secondary metabolites produced by plants to check their properties and to evaluate their possible use in the industry. Also, scientific interest in these metabolites is increasing today with the search of new antimicrobial agents due to the increasing development of the resistance pattern of microorganisms to most currently used antimicrobial drugs. A number of natural products such as phenolics, flavonoids, coumarins, curcuminoids or

\footnotetext{
* Correspondence: naceur.hamdi@isste.rnu.tn

'College of Science and Arts, Al-Rass, Qassim University, P.O. Box 53, Qassim, Saudi Arabia

${ }^{3}$ Higher Institute of Environmental Science and Technology, Borj-Cédria,

TUNISIA" \& "University of Carthage, Carthage, Tunisia

Full list of author information is available at the end of the article
}

terpenes have been characterised as metabolites which allow easy transport across cell membranes to induce different biological activities, including antioxidant, antiinflammatory and anticholinesterase effects [4].

Pelargonium graveolens (P. graveolens) is a plant about which technical and scientific knowledge is scarce. It belongs to the Geraniaceae family, and its leaves are popularly used as flavouring, insect repellent, in perfume and in aromatherapy for the treatment of gastrointestinal diseases, throat infections, and bleeding [5]. Previous reports have documented the antimicrobial activity of some Geraniaceae extracts and their constituents against several bacterial and fungal pathogens [6]. These studies have provided little information on the identity of the chemical constituents of the essential oil of this species or its biological activities.

The aim of the present study was to investigate the chemical composition of the Tunisian $P$. graveolens essential oil and its potent antimicrobial effect as well as that of the organic extracts. Total phenolic and flavonoids contents of the extracts were also determined.

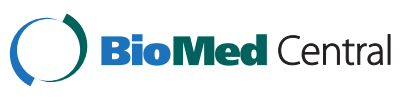

(c) 2012 Ben Hsouna and Hamdi; licensee BioMed Central Ltd. This is an Open Access article distributed under the terms of the Creative Commons Attribution License (http://creativecommons.org/licenses/by/2.0), which permits unrestricted use,

distribution, and reproduction in any medium, provided the original work is properly cited. 


\section{Materials and methods Chemicals}

Gentamicin and Amphotericin B were purchased from Sigma-Chemical (France). Folin-Ciocalteu reagent, sodium carbonate $\left(\mathrm{Na}_{2} \mathrm{CO}_{3}\right)$ and other solvents were of analytical grade and were freshly prepared in distilled water.

\section{Plant material}

P. graveolens leaves were collected from Chebba (Tunisia, $35.23^{\circ} \mathrm{N}$ and $11.11^{\circ} \mathrm{E}$ ) in April 2009. After the botanical identification of the species, a voucher specimen (LBPes 08) was deposited in the Herbarium of the Laboratory of Biopesticides (Center of Biotechnology of Sfax, Tunisia) for future reference.

\section{Preparation of plant organic extracts}

A portion of dried leaves (100 g) of P. graveolens was placed in a soxhlet apparatus. Extraction was performed with $500 \mathrm{ml}$ of an appropriate solvent with increased polarity for $48 \mathrm{~h}$ at a temperature not exceeding the boiling point of the solvent. The extract was filtered through a $45 \mu \mathrm{m}$ filter and concentrated under vacuum. In this experiment three solvents were used: $n$-hexane, ethyl acetate and methanol [7]. The resulting three solutions were concentrated in vacuous to dryness to give $n$ hexane extract $\mathrm{HE}(4 \mathrm{~g})$, ethyl acetate extract EtOAcE (10 g) and methanol extract MeOHE (12 g). The remaining residue was extracted by water infusion and lyophilised to give water extract WE (15 g) and the resulting powder material was stored until tested. The stock solutions were kept at $4^{\circ} \mathrm{C}$ in the dark until further analysis.

\section{Essential oil extraction}

The oil extraction was obtained from $0.5 \mathrm{~kg}$ fresh plant by steam distillation during $3 \mathrm{~h}$ using a Clevenger-type apparatus $[7,8]$. The aqueous phase was extracted with dichloromethane $(3 \times 50 \mathrm{ml})$ and dried with anhydrous sodium sulphate. For the determination of the procedure yield, the solvent was evaporated using a rotavapory vacuum evaporator to afford $2.5 \mathrm{~g}$. The resulting essential oil (EO) was stored at $4^{\circ} \mathrm{C}$ prior to further analyses. The EO was solubilised in $n$-Hexane for gas chromatography and mass spectrometry analysis.

\section{Total phenolic content}

Total phenolic content (TPC) was determined using the Folin-Ciocalteu method [9] adapted to a microscale. Briefly, $10 \mu \mathrm{l}$ of diluted sample solution were shaken for $5 \mathrm{~min}$ with $50 \mu \mathrm{l}$ of Folin-Ciocalteu reagent. Then $150 \mu \mathrm{l}$ of $20 \% \mathrm{Na}_{2} \mathrm{CO}_{3}$ were added and the mixture was shaken once again for $1 \mathrm{~min}$. Finally, the solution was brought up to $790 \mu \mathrm{l}$ by the addition of distilled water. After $90 \mathrm{~min}$, the absorbance at
$760 \mathrm{~nm}$ was evaluated using a spectrophotometer SmartSpecT ${ }^{\mathrm{m}} 3000$ (Bio-Rad; Hercules, CA, USA). Gallic acid was used as an internal standard for the calibration curve. The phenolic content was expressed as mg of gallic acid equivalent per gram of dry sample (mg GAE/g) using the linear equation based on the calibration curve.

\section{Determination of total flavonoids content}

The flavonoids content in the extracts was determined spectrophotometrically according to Quettier-Deleu et al. [10], using a method based on the formation of a complex flavonoid-aluminium, having the maximum absorption at $430 \mathrm{~nm}$. The flavonoids content was expressed in mg of quercetin equivalent per gram of dry plant extract (mg QE/g).

\section{Gas chromatography-mass spectrometry (GC-MS)}

The EO analysis was performed on a GC-MS HP model 6980 inert MSD (Agilent Technologies, J\&W Scientific Products, Palo Alto, CA, USA), equipped with an Agilent Technologies capillary HP-5MS column (60 m length; $0.25 \mathrm{~mm}$ i.d.; $0.25 \mathrm{~mm}$ film thickness), and coupled to a mass selective detector (MSD5973, ionization voltage $70 \mathrm{eV}$; all Agilent, Santa Clara, CA) [11]. The carrier gas was $\mathrm{He}$ and was used at $1.2 \mathrm{~mL} / \mathrm{min}$ flow rate. The oven temperature program was as follows: $1 \mathrm{~min}$ at $100^{\circ} \mathrm{C}$ ramped from 100 to $280^{\circ} \mathrm{C}$ at $5^{\circ} \mathrm{C} \mathrm{min}{ }^{-1}$ and $25 \mathrm{~min}$ at $280^{\circ} \mathrm{C}$. The chromatograph was equipped with a split/split less injector used in the split less mode. Components identification was assigned by matching their mass spectra with Wiley $275 \mathrm{~L}$ and NIST library data, standards of the main components [12].

\section{Antimicrobial activity}

\section{Microorganisms and growth conditions}

Authentic pure cultures of bacteria and fungi were obtained from international culture collections (ATCC) and the local culture collection of the Center of Biotechnology of Sfax, Tunisia. They included Grampositive bacteria: Bacillus subtilis ATCC 6633, Bacillus cereus ATCC 14579, Staphylococcus aureus ATCC 25923, Staphylococcus epidermidis ATCC 12228, Enterococcus faecalis ATCC 29212, Micrococcus luteus ATCC 1880, Listeria monocytogenes (food isolate 2132) and Gram-negative bacteria: Salmonella enterica (food isolate), Klebsiella pneumoniae ATCC 10031.

The following fungal strains were also tested: Aspergillus niger CTM 10099, Aspergillus flavus (food isolate), Fusarium graminearum (ISPAVE 271), Fusarium oxysporum (CTM10402), Fusarium culmorum (ISPAVE 21w), Rhizopus nigricans (CTM10150), and Alternaria alternata (CTM 10230).

The bacterial strains were cultivated in Muller-Hinton agar $(\mathrm{MH})$ (Oxoid Ltd, UK) at the appropriate 
temperature for each strain at $37^{\circ} \mathrm{C}$ and fungi were cultured on Potatoes Dextrose agar (PDA) medium at $28^{\circ} \mathrm{C}$. Working cultures were prepared by inoculating a loopful of each test bacteria in $3 \mathrm{ml}$ of Muller-Hinton broth $(\mathrm{MH})$ (Oxoid Ltd, UK) and were incubated at $37^{\circ} \mathrm{C}$ for 12 hours. For the test, final inoculum concentrations of $10^{6} \mathrm{CFU} / \mathrm{ml}$ bacteria were used. Fungal spore suspensions were collected from the surface of such fungal colonies by gentle scraping with a loop and suspended in $10 \mathrm{ml}$ Potato Dextrose broth (PDB).

This suspension was mixed vigorously by vortexing for 15-20 min. The spore suspension stock was diluted to obtain a concentration of $10^{6}$ spores $/ \mathrm{ml}$ (measured by Malassez blade).

\section{Agar diffusion method}

The antimicrobial activity of the $P$. graveolens was evaluated by means of agar-well diffusion assay according to Güven et al. [13] with some modifications. Fifteen millilitres of the molten agar $\left(45^{\circ} \mathrm{C}\right)$ were poured into sterile petri dishes (Ø $90 \mathrm{~mm}$ ). Working cell suspensions were prepared and $100 \mu \mathrm{l}$ were evenly spreaded onto the surface of the agar plates of Mueller-Hinton agar (Oxoid Ltd, UK) for bacteria, or potatoes dextrose agar medium (Oxoid Ltd, UK) for fungi. Once the plates had been aseptically dried, $06 \mathrm{~mm}$ wells were punched into the agar with a sterile Pasteur pipette. The P. graveolens oils and extracts were dissolved in dimethylsulfoxide/water $(1 / 1)$ and sterile water to a final concentration of $50 \mathrm{mg} / \mathrm{ml}$. Thus, $50 \mu \mathrm{l}$ were placed into the wells and the plates were incubated at $37^{\circ} \mathrm{C}$ for $24 \mathrm{~h}$ for bacterial strains and $72 \mathrm{~h}$ for fungi at $28^{\circ} \mathrm{C}$. Gentamicin $(15 \mu \mathrm{g} /$ wells), Amphotericin B (20 $\mu \mathrm{g} /$ wells $)$ and DMSO served as positive and negative control. Antimicrobial activity was evaluated by measuring the diameter of circular inhibition zones around the well. Tests were performed in triplicate.

\section{Determination of MIC and MFC}

Minimum inhibitory concentrations (MICs) of $P$. graveolens were determined according to Gulluce et al. [14] against a panel of 21 microorganisms representing different species of different ecosystems. The test was performed in sterile 96-well microplates with a final volume in each microplate well of $100 \mu \mathrm{l}$. A stock solution of the $P$. graveolens $(50 \mathrm{mg} / \mathrm{ml})$ was prepared in dimethylsulfoxide/water (1/9). The inhibitory activity of the EO and organic extracts was properly prepared and transferred to each well in order to obtain a twofold serial dilution of the original sample and to produce the concentration range of $0.039-10 \mathrm{mg} / \mathrm{ml}$. To each test well $10 \mu \mathrm{l}$ of cell suspension were added to final inoculum concentrations of $10^{6} \mathrm{CFU} / \mathrm{ml}$ for bacteria and $10^{5}$ spores/ml for fungus. Positive growth control wells consisted of bacteria or fungi only in their adequate medium. Dimethylsulfoxide/water (1/9) was used as negative control. The plates were then covered with the sterile plate covers and incubated at $37^{\circ} \mathrm{C}$ for $24 \mathrm{~h}$ for bacterial strains and $72 \mathrm{~h}$ for fungi at $28^{\circ} \mathrm{C}$. The $\mathrm{MIC}$ was defined as the lowest concentration of the total essential oil at which the microorganism does not demonstrate visible growth after incubation. As an indicator of microorganism growth, $25 \mu \mathrm{l}$ of Thiazolyl Blue Tetrazolium Bromide (MTT), indicator solution $(0.5 \mathrm{mg} / \mathrm{ml})$ dissolved in sterile water were added to the wells and incubated at $37^{\circ} \mathrm{C}$ for $30 \mathrm{~min}$ [15]. The colourless tetrazolium salt acts as an electron acceptor and is reduced to a red-coloured formazan product by biologically active organisms. Where microbial growth was inhibited, the solution in the well remained clear after incubation with MTT. The minimum fungicidal concentrations (MFCs) were determined by serial subcultivation of $10 \mu \mathrm{l}$ in Potatoes Dextrose agar (PDA) plates and incubated for $72 \mathrm{~h}$ at $28^{\circ} \mathrm{C}$. The lowest concentration with no visible growth was defined as the MFC, indicating $\geq$ 99.5\% killing of the original inoculum. DMSO and ethanol were used as a negative control.

The determinations of MIC, MBC and MFC values were done in triplicate.

\section{Statistical analysis}

The experimental results concerning this study were expressed as means \pm standard deviation of three parallel measurements. The significance of difference was calculated by Student's $t$ test, and values $p<0.05$ and $p<$ 0.001 were considered to be significant and highly significant respectively. Correlation and regression analysis was carried out using EXCELL program (Microsoft Corporation, USA).

\section{Results and discussion}

Chemical composition of the leaf essential oil

The hydrodistillation of $P$. graveolens leaves gave yellow to brownish oil. GC-MS analyses of the essential oil led to the identification of 42 different compounds, listed in Table 1 according to their elution order on a HP-5MS column. The oil contained a complex mixture mainly of monoterpene hydrocarbons with some other essential phytochemicals. The prominent components were Linalool (6.54\%), Citronellol (27.53\%), Geraniol (25.85\%), 6Octen-1-ol, 3,7-dimethyl-, formate (8.75) and $\Delta$ Selinene (8.15\%).

\section{Extraction yield, total phenolic and flavonoids contents determination}

The extraction yield varied between 5.7\% and $21.5 \%$ depending on the extraction solvent with the following order: $\mathrm{WE}>\mathrm{MeOHE}>$ EtoAcE > HE (Table 2). 
Table 1 Chemical composition of essential oil isolated by hydrodistillation from $P$. graveolens leaves

\begin{tabular}{|c|c|c|c|}
\hline Pic & Compounds $^{a}$ & $\begin{array}{c}\mathbf{R t} \\
(\mathrm{min})\end{array}$ & $\begin{array}{c}\% \text { of } \\
\text { abundance }\end{array}$ \\
\hline 1 & a-Pinene & 8.829 & 0.28 \\
\hline 2 & $\Delta$.3-Carene & 11.724 & 0.07 \\
\hline 3 & E- $\beta$-Ocimene & 12.033 & 0.17 \\
\hline 4 & Linalool & 14.030 & 6.54 \\
\hline 5 & E-ROSE OXIDE & 14.264 & 0.32 \\
\hline 6 & Z-ROSE OXIDE & 14.739 & 0.12 \\
\hline 7 & Isomenthone & 15.523 & 0.18 \\
\hline 8 & L-menthone & 15.912 & 6.22 \\
\hline 9 & Menthomenthol & 16.399 & 0.17 \\
\hline 10 & a-terpineol & 16.639 & 0.30 \\
\hline 11 & Citronellol & 17.961 & 27.53 \\
\hline 12 & Z-Citral & 18.098 & 0.55 \\
\hline 13 & Geraniol & 18.779 & 25.85 \\
\hline 14 & 6-Octen-1-ol, 3,7-dimethyl-, formate & 19.111 & 8.75 \\
\hline 15 & 2,6-Octadien-1-ol, 3,7-dimethyl-, formate & 19.780 & 2.70 \\
\hline 16 & Z-2,6-Dimethyl-2,6-octadiene & 21.062 & 0.21 \\
\hline 17 & a.-Copaene & 21.714 & 0.18 \\
\hline 18 & acetate de Geranyl & 21.869 & 0.74 \\
\hline 19 & ß. BOURBONENE & 21.961 & 0.22 \\
\hline 20 & E-(.ß.)-CARYOPHYLLENE & 22.853 & 0.33 \\
\hline 21 & A.-Cubebene & 23.580 & 0.11 \\
\hline 22 & A-Humulene & 23.711 & 0.12 \\
\hline 23 & Aromadendrene & 23.895 & 0.17 \\
\hline 24 & Acetate & 24.146 & 0.57 \\
\hline 25 & $\Delta$-germacrene & 24.415 & 1.50 \\
\hline 26 & Ledene & 24.747 & 0.70 \\
\hline 27 & Acide Propanoique & 25.090 & 0.15 \\
\hline 28 & $\Delta$-Cadinene & 25.405 & 0.59 \\
\hline 29 & A-agarofuran & 25.989 & 0.19 \\
\hline 30 & Acide Butanoique & 26.206 & 0.18 \\
\hline 31 & Acide-2-Butenoique & 26.887 & 1.43 \\
\hline 33 & geranyl propionate & 27.213 & 0.15 \\
\hline 34 & Ledol & 27.339 & 0.15 \\
\hline 35 & $\Delta$-Selinene & 27.803 & 8.15 \\
\hline 36 & cadina-1,4-diene & 27.888 & 0.25 \\
\hline 37 & $\gamma$-Eudesmol & 27.974 & 0.12 \\
\hline 38 & Valencene & 28.072 & 0.32 \\
\hline 39 & a-Cadinol & 28.209 & 0.39 \\
\hline 40 & tau.-Cadinol & 28.461 & 1.21 \\
\hline 41 & Z-2,6-Dimethyl-2,6-octadiene & 28.621 & 0.19 \\
\hline 42 & tiglate de geranyl & 29.433 & 1.92 \\
\hline
\end{tabular}

${ }^{a}$ Identification of components based on GC-MS Wiely 7.0 version library.

${ }^{\mathrm{b}}$ Rt: retention time.
Table 2 Yields extracts, amounts of total flavonoids, and total phenolic compounds of $\boldsymbol{P}$. graveolens leaves crude extracts

\begin{tabular}{lccc}
\hline Extract & $\begin{array}{c}\text { Yield } \\
\text { (\%) }\end{array}$ & $\begin{array}{c}\text { Phenolic } \\
\text { content } \mathbf{~ m g ~ G A E / g}\end{array}$ & $\begin{array}{c}\text { Flavonoid } \\
\text { content mg QE/g }\end{array}$ \\
\hline$n$-Hexane & 5.70 & $59.50 \pm 3.95$ & $11.50 \pm 1.95$ \\
Ethyl acetate & 14.25 & $144.25 \pm 2.75$ & $12.25 \pm 3.70$ \\
Methanol & 17.25 & $145 \pm 4.00$ & $10.90 \pm 3.00$ \\
Water & 21.50 & $140.75 \pm 8.25$ & $21.75 \pm 4.70$ \\
\hline
\end{tabular}

(mg GAE /g): $\mathrm{mg}$ of gallic acid equivalent per $\mathrm{g}$ of dry plant extract. (mg QE/g): $m g$ of quercetin equivalent per $\mathrm{g}$ of dry plant extract.

Naturally occurring phenolic compounds, including phenolic acids, flavonoids, tannins, coumarins and others have been reported to be significantly associated with the biological activities of plant and food extract [16]. In the present study, the total phenolic compounds in the organic extracts of $P$. graveolens were determined. These compounds showed differences in their total contents depending on solvents polarities. The TPC values of the successive $P$. graveolens leaves extracts varied between 140.75 and $145 \mathrm{mg}$ GAG/g and were in the following order: $\mathrm{MeOHE}>$ EtoAcE > WE > HE (Table 2). Total flavonoids content ranged from 10.90 to $21.75 \mathrm{mg} \mathrm{QE} / \mathrm{g}$. Water extract had the highest level with $21.75 \mathrm{QE} / \mathrm{g}$, while hexane had the lowest amounts (10.90 mg QE /g). As can be seen, high phenol content was not always accompanied by high flavonoid concentrations. This result was in agreement with the reports of Boukhris et al.; Hertog et al. and Yen et al., which proved that the methanol is the most suitable solvent for the extraction of phenolic compounds $[17,19]$. The total phenolic content level in our case may be related to the hard climate conditions (high temperature and solar exposure, dryness, short growing season). Based on the phenolic and flavonoid content, methanol was the best solvents to be used for $P$. graveolens phenolic compounds extraction compared to the other solvents due to their suitable polarities. These results revealed that $P$. graveolens extracts contains more significant phenolics and flavonoids contents than those of some plants, commonly used as antioxidants in previous studies $[20,21]$.

\section{Antibacterial activity}

Plant extracts are widely claimed to have a broadspectrum antibacterial activity and are considered as a main source for the search of lead compounds. The antimicrobial activities of $P$. graveolens essential oil and extracts against the tested microorganisms were qualitatively and quantitatively assessed by the presence or absence of inhibition zones, MIC and MBC values. The 
results are given in Tables 3 and 4. Among the tested extracts, only EtOAcE and MeOHE extracts exhibited an antimicrobial activity. HE and WE remained inactive in the range of the used concentration $(4 \mathrm{mg} /$ wells). Active extracts showed a potent antimicrobial activity against both Gram-positive and Gram-negative bacteria. The inhibition zone diameters and MIC values were in the range of $17-27 \mathrm{~mm}$ and $0.039-1.25 \mathrm{mg} / \mathrm{ml}$ for the ethyl acetate extract and $12-20 \mathrm{~mm}$ and 0.078 $2.5 \mathrm{mg} / \mathrm{ml}$ for the methanol one, respectively. Compared to the antibacterial activity of $\mathrm{MeOH}$ extract, and of the EtOAc showed a significant one $(\mathrm{p}<0.05)$. Negative control did not show any inhibitory effect against the tested bacteria.

Also, our results showed that the essential oil of $P$. graveolens had great potential for antimicrobial activity against a panel of microorganisms. The maximum inhibition zone diameters and MIC values for bacterial strains, which were sensitive to the EO, were in the range of $13-26 \mathrm{~mm}$ and $0.312-10 \mathrm{mg} / \mathrm{ml}$, respectively (Tables 3 and 4).
On the basis of inhibition zone diameters, MIC and MBC values, Staphylococcus aureus was more sensitive to the EO than the other Gram positive bacteria with inhibition zone diameter of $24 \mathrm{~mm}$ and $\mathrm{MIC}$ and $\mathrm{MBC}$ values of 0.312 and $0.625 \mathrm{mg} / \mathrm{ml}$ respectively. Our results are in good agreement with the findings of Hussain [22] who reported that Gram positive bacteria are more sensitive to plant essential oils than Gram negative bacteria, especially $E$. coli [23]. The resistance of Gram negative bacteria against essential oils has been attributed to the presence of a hydrophilic outer membrane containing a hydrophilic polysaccharide chain, which acts as a barrier hydrophobic essential oil [24]. The intense antimicrobial properties of essential oils from the leaves of $P$. graveolens was suspected to be associated with their high contents of oxygenated monoterpene appeared more active against the tested Gram positive than Gram negative bacteria. This result was in agreement with many studies realized on other plant species like E. robusta, E. alba, E. camadulensis, E. citriodora, E. globulus, E. saligna [23].

Table 3 Antimicrobial activities of $P$. graveolens organic extracts and essential oil against fungi, foodborne and spoiling bacteria (4 $\mathrm{mg} /$ well)

\begin{tabular}{|c|c|c|c|c|c|c|}
\hline \multirow[b]{2}{*}{ Extracts } & \multicolumn{6}{|c|}{ Inhibition zones diameters $(\mathrm{mm})^{\mathrm{a}}$} \\
\hline & $\overline{\mathrm{HE}}$ & EtOAc & $\mathrm{MeOH}$ & WE & EO & Genta $^{b}$ \\
\hline \multicolumn{7}{|l|}{ Strains } \\
\hline \multicolumn{7}{|l|}{ Bacterial strains } \\
\hline \multicolumn{7}{|l|}{ Gram positive } \\
\hline Bacillus subtilis ATCC 6633 & - & $27 \pm 0.1$ & $14 \pm 0.4$ & - & $22 \pm 0.0$ & $20 \pm 0.2$ \\
\hline Bacillus cereus ATCC 14579 & - & $17 \pm 0.3$ & $12 \pm 0.8$ & - & $26 \pm 0.2$ & $20 \pm 0.4$ \\
\hline Staphylococcus aureus ATCC 25923 & - & $25 \pm 0.0$ & $13 \pm 0.6$ & - & $24 \pm 0.3$ & $25 \pm 0.8$ \\
\hline Staphylococcus epidermis ATCC 12228 & - & $24 \pm 0.6$ & $20 \pm 0.3$ & - & $14 \pm 0.4$ & $20 \pm 0.5$ \\
\hline Enterococcus faecalis ATCC29212 & - & $18 \pm 0.1$ & 0 & - & $20 \pm 0.3$ & $12 \pm 0.2$ \\
\hline Micrococcus luteus ATCC 1880 & - & $21 \pm 0.4$ & $18 \pm 0.5$ & - & $15 \pm 0.6$ & $20 \pm 0.7$ \\
\hline Listeria monocytogenes (food isolate 2132) & - & $19 \pm 0.2$ & $18 \pm 0.1$ & - & 0 & $15 \pm 0.0$ \\
\hline \multicolumn{7}{|l|}{ Gram negative } \\
\hline Salmonella enterica (food isolate) & - & $24 \pm 0.2$ & $14 \pm 0.3$ & - & $14 \pm 0.1$ & $18 \pm 0.8$ \\
\hline Klebsiella pneumoniae ATCC 10031 & - & $18 \pm 0.2$ & $15 \pm 0.1$ & - & $13 \pm 0.3$ & $12 \pm 0.5$ \\
\hline \multicolumn{7}{|l|}{ Fungal strains } \\
\hline Aspergillus niger CTM 10099 & - & $34 \pm 0.1$ & $16 \pm 0.2$ & - & $18 \pm 0.7$ & $15 \pm 0.9$ \\
\hline Aspergillus flavus (food isolate) & - & $24 \pm 0.2$ & $18 \pm 0.5$ & - & $22 \pm 0.2$ & $10 \pm 0.3$ \\
\hline Fusarium graminearum (ISPAVE271) & - & $15 \pm 0.7$ & $13 \pm 0.4$ & - & $16 \pm 0.4$ & $14 \pm 0.5$ \\
\hline Fusarium oxysporum (CTM 10402) & - & $14 \pm 0.3$ & $23 \pm 0.7$ & - & $26 \pm 0.1$ & $14 \pm 0.2$ \\
\hline Fusarium culmorum (ISAVE21w) & - & $14 \pm 0.2$ & $17 \pm 0.5$ & - & $18 \pm 0.6$ & $12 \pm 0.7$ \\
\hline Alternaria alternata (CTM 10230) & - & $14 \pm 0.1$ & $17 \pm 0.6$ & - & $17 \pm 0.5$ & $14 \pm 0.6$ \\
\hline Rhizopus nigricans (CTM10150) & - & $17 \pm 0.5$ & $22 \pm 0.2$ & - & $26 \pm 0.1$ & $\mathrm{Nt}$ \\
\hline
\end{tabular}

Values are given as mean \pm S.D. of triplicate experiment.

${ }^{a}$ Diameters of inhibition zone of various $P$. graveolens organic and essential oil extracts including 6 mm disk diameters.

Abreviations: Genta ${ }^{\mathrm{b}}$ : Gentamicin was used as a standard antibiotic at a concentration of $15 \mu \mathrm{g} /$ well.

Amphoc: Amphotrycine B was used as a standard antifungal at a concentration of $20 \mu \mathrm{g} /$ well. 
Table 4 Determined MIC, MBC and MFC values of $P$. graveolens organic extracts and essential oil against bacterial species and fungal strains

\begin{tabular}{|c|c|c|c|c|c|c|c|}
\hline Bacteria & Extracts & EtOAct & & $\mathrm{MeOH}$ & & EO & \\
\hline Gram positive & & MIC & MBC & MIC & MBC & MIC & MBC \\
\hline Bacillus subtilis ATCC 6633 & & 0.156 & 5 & 0.078 & 0.156 & 5 & 5 \\
\hline Bacillus cereus ATCC 14579 & & 0.039 & 20 & 0.156 & 20 & 10 & 20 \\
\hline Staphylococcus aureus ATCC 25923 & & 0.625 & 20 & 2.5 & 10 & 0.312 & 0.625 \\
\hline Staphylococcus epidermis ATCC 12228 & & 0.156 & 0.312 & & & 5 & 10 \\
\hline Enterococcus faecalis ATCC29212 & & 1.25 & 10 & 0 & 0 & 2.5 & 20 \\
\hline Micrococcus luteus ATCC1880 & & 0.312 & 20 & 2.5 & 10 & 10 & 10 \\
\hline Listeria monocytogenes (food isolate 2132) & & 0.156 & 0.625 & 2.5 & 5 & 2.5 & 10 \\
\hline Gram negative & & & & & & & \\
\hline Salmonella enterica (food isolate) & & 0.078 & 2.5 & 0.312 & 5 & 5 & 5 \\
\hline Klebsiella pneumoniae ATCC 10031 & & 0.312 & 5 & 0.312 & 10 & 10 & 10 \\
\hline Fungal strains & & MIC & MFC & MIC & MFC & MIC & MFC \\
\hline Aspergillus niger CTM 10099 & & 0.312 & 2.5 & 1.25 & 20 & 0.625 & 5 \\
\hline Aspergillus flavus (food isolate) & & 0.625 & 5 & 2.5 & 20 & 1.25 & 10 \\
\hline Fusarium graminearum (ISPAVE271) & & 1.25 & 10 & 0.625 & 5 & 0.312 & 5 \\
\hline Fusarium oxysposium (ISAVE21w) & & 1.25 & 5 & 0.312 & 2.5 & 0.156 & 5 \\
\hline Alternaria alternata (CTM 10230) & & 0.625 & 5 & 1.25 & 10 & 0.625 & 5 \\
\hline Rhizopus nigrcans (CTM 101052) & & 1.25 & 20 & 1.25 & 20 & 0. & 10 \\
\hline
\end{tabular}

Values are expressed on $\mathrm{mg} / \mathrm{ml}$.

MIC: Minimum inhibitory concentrations.

MBC: Minimum bactericidal concentrations.

MFC: Minimum fungicidal concentrations.

EtOAcE: ethyl acetate extract.

MeOHE: methanol extract.

EO: essential oil.

Furthermore, EtOAc and MeOHE of $P$. graveolens showed a potent inhibition for B. subtilis, L. monocytogenes and $S$. enterica with MIC of 0.156 and $0.078 \mathrm{mg} / \mathrm{ml}$ respectively. Infections caused by these bacteria, especially those with multi-drugs resistance, are among the most difficult to treat with conventional antibiotics. In the current study, the growth of B. subtilis was remarkably inhibited by the ethyl acetate extract of P. graveolens $(\mathrm{IZ}=27 \mathrm{~mm})$. These results show that $P$. graveolens EtOAc organic extract can be used to minimize problems of drug resistance and protect foods against multiple pathogenic bacteria. Our data suggest that antibacterial activities might be related to the phenolic compounds found in the EtOAC and $\mathrm{MeOH}$ extracts.

\section{Antifungal activity}

Contamination by Aspergillus, Fusarium and Alternaria species especially with their respective mycotoxins is considered as a challenge for the pharmaceutical and food industries. The current study reports the capacity of the crude extracts and essential oil of $P$. graveolens to control Aspergillus sp., Fusarium sp. and Alternaria alternata strains. Among the tested extracts, only $\mathrm{MeOH}$ and EtOAc exhibited an antifungal activity.
Results showed a strong inhibitory effect of EtOAc on the growth of $A$. niger and $A$. flavus with inhibition zone diameters of 24-34 mm and MIC values of 0.312 and $0.625 \mathrm{mg} / \mathrm{ml}$ respectively (Tables 3 and 4). Also, the $P$. graveolens $\mathrm{EO}$ exhibited an antifungal activity against Fusarium and Aspergillus sp. such as A. niger and $A$. flavus which are responsible for food spoilage. The maximum inhibition zone diameters were $14-34 \mathrm{~mm}$ and MIC values ranged from 0.078 to $1.25 \mathrm{mg} / \mathrm{ml}$ (Table 3 and Table 4). The inhibition zone of the EO against Aspergillus sp. was recorded as $18-22 \mathrm{~mm}$ and the minimum inhibition concentration values were $0.625-1.25 \mathrm{mg} / \mathrm{ml}$. Essential oil is a complex mixture of compounds with low molecular weights and the antimicrobial effect of total oil is related to one or a few principles

To the best of our knowledge, this is the first study providing data on the antifungal activity of the essential oil and organic extracts of $P$. graveolens plants evaluated against a wide range of fungal strains. Findings revealed that the extracts of this aromatic plant could be useful as an alternative antimicrobial agent in natural medicine for the treatment of many infectious diseases. 


\section{Conclusion}

P. graveolens is a medicinal and edible herb growing wild in Tunisia and used for a long time in Mediterranean cuisine, not only to improve or modify food flavor, but also to avoid its deterioration. In the present work we report the chemical composition of the Tunisian $P$. graveolens essential oil which revealed 42 main components. We also investigated the antimicrobial activities of the essential oil and organic extracts from this herb. The ethyl acetate extract of $P$. graveolens, revealed a very important in vitro antibacterial activity on the studied bacteria, confirmed by low minimum inhibitory concentrations (MIC). It can therefore be used as a natural antimicrobial agent for the treatment of several infectious diseases. Furthermore studies are needed for the purification of the methanol extract and the identification of active molecules.

Our results are a contribution to a better valorisation of this medicinal plant. Several other biological tests will be worthwhile to search for more eventual activities of this plant to characterize active principles, and assess toxicity by laboratory assays.

\section{Competing interests}

The authors declare that they have no competing interests.

\section{Authors' contributions}

$\mathrm{ABH}$ and $\mathrm{NH}$ designed the experiments, analyzed the data and drafted the manuscript. All authors read, correct and approve the final manuscript.

\section{Acknowledgement}

We thank the staff of the Research laboratory of Arras College of Applied health Sciences, Qassim University (KSA) for help and fruitful discussions.

\section{Author details}

${ }^{1}$ College of Science and Arts, Al-Rass, Qassim University, P.O. Box 53, Qassim, Saudi Arabia. ${ }^{2}$ Bio-pesticides Team (LPIP), Center of Biotechnology of Sfax, P. B. 1177, Sfax 3018, Tunisia. ${ }^{3}$ Higher Institute of Environmental Science and Technology, Borj-Cédria, TUNISIA" \& "University of Carthage, Carthage, Tunisia.

Received: 4 October 2012 Accepted: 28 November 2012 Published: 5 December 2012

\section{References}

1. Tepe B, Daferera D, Sokmen A, Sokmen M, Polissiou M: Antimicrobial and antioxidant activities of essential oil and various extracts of salvia tomentosa miller (lamiaceae). Food Chem 2005, 90:333-340.

2. Khanna D, Sethi G, Ahn KS, Pandey MK, Kunnumakkara AB, Sung B, Aggarwal A, Aggarwal BB: Natural products as a gold mine for arthritis treatment. Curr Opin Pharmacol 2007, 7:344-351.

3. Fusco D, Colloca G, Lo Monaco MR, Cesari M: Rationale for antioxidant supplementation in sarcopenia. J Clin Interv Aging 2007, 2:377-387.

4. Loizzo MR, Tundis R, Conforti F, Saab AM, Statti GA, Menichini F: Composition and a-amylase inhibitory effect of essential oils from cedrus libani. Fitoterapia 2007, 78:323-326.

5. Saraswathi J, Venkatesh K, Baburao N, Hilal MH, Roja Rani A: Phytopharmacological importance of pelargonium species. Journal of Medicinal Plants Research 2011, 5:2587-2598.

6. Mativandlela SPN, Lall N, Meyer JJN: Antibacterial, antifungal and antitubercular activity of (the roots of) Pelargonium reniforme (CURT) and Pelargonium sidoides (DC) (Geraniaceae) root extracts. South African Journal of Botany 2006, 72:232-237.
7. Ben Hsouna A, Trigui M, Ben Mansour R, Mezghani Jarraya R, Damak M, Jaoua S: Chemical composition, cytotoxicity effect and antimicrobial activity of ceratonia siliqua essential oil with preservative effects against Listeria inoculated in minced beef meat. Int J Food Microbiol 2011, 148:66-72.

8. Sartoratto A, Machado ALM, Delarmelina C, Figueira GM, Duarte MCT, Rehder VLG: Composition and antimicrobial activity of essential oils from aromatic plants used in brazil. Braz J Microbiol 2004, 35:275-280.

9. Ben Hsouna A, Culioli MG, Blache Y, Jaoua S: Antioxidant constituents from lawsonia inermis leaves: isolation, structure elucidation and antioxidative capacity. Food Chem 2011, 125:193-200.

10. Quettier-Deleu C, Gressier B, Vasseur J, Dine T, Brunet C, Luyck M, Cazin M, Cazin JC, Bailleul F, Trotin F: Phenolic compounds and antioxidant activities of buckwheat (fagopyrum esculentum moench) hulls and flour. J Ethnopharmacol 2000, 72:35-42.

11. Fendri I, Chaari A, Dhouib A, Jlassi B, Carriere F, Sayadi S, Abdelkafi S: Isolation, identification and characterization of a new lipolytic pseudomonas sp., strain AHD-1, from Tunisian soil. Environ Technol 2010, 31:87-95.

12. Barouh N, Abdelkafi S, Fouquet B, Pina M, Scheirlinckx F, Carrière F, Villeneuve P: Neutral lipid characterization of non-water-soluble fractions of carica papaya latex. Journal of American Oil Chemist Society 2010, 87:987-995.

13. Güven $K$, Yücel $E$, Çetintaş F: Antimicrobial activities of fruits of crataegus and pyrus species. Pharm Biol 2006, 44:79-83.

14. Gulluce M, Sahin F, Sokmen M, Ozer H, Daferera D, Sokmen A, Polissiou M, Adiguzel A, Ozkan H: Antimicrobial and antioxidant properties of the essential oils and methanol extract from mentha longifolia L. ssp. Longifolia. Food Chem 2007, 103:1449-1456.

15. Shojaee-Aliabadi S, Hosseini H, Mohammadifar MA, Mohammadi A, Ghasemlou M, Mahdi Ojagh S, Marzieh Hosseini S, Khaksar R: Characterization of antioxidant-antimicrobial k-Carrageenan films containing satureja hortensis essential oil. Int J Biol Macromol 2012, In Press.

16. Gupta S, Prakash J: Studies on indian green leafy vegetables for their antioxidant activity. Plant Foods Hum Nutr 2009, 64:39-45.

17. Boukhris M, Simmonds MSJ, Sayadi S, Bouaziz M: Chemical composition and biological activities of polar extracts and essential oil of rosescented geranium, Pelargonium graveolens. Phytother Res 2012, doi:10.1002/ptr.4853.

18. Hertog MGL, Hollman PCH, Van de Putte B: Content of potentially anticarcinogenic flavonoids of tea infusions, wines, and fruit juices. Journal Agricultrual Food Chemistry 1993, 41:1242-1246.

19. Yen $G$, Wu S, Duh P: Extraction and identification of antioxidant components from the leaves of mulberry (morus alba L.). Journal Agricultrual Food Chemistry 1996, 44:1687-1690.

20. Ardestani A, Yazdanparast R: Antioxidant and free radical scavenging potential of achillea santolina extracts. Food Chem 2007, 104:21-29.

21. Djeridane A, Yousfi M, Nadjemi B, Boutassouna D, Stocker P, Vidal N: Antioxidant activity of some Algerian medicinal plants extracts containing Phenolic compounds. Food Chem 2006, 97:654-660.

22. Hussain Al, Anwar F, Shahid M, Ashraf M, Przybylski R: Chemical composition, antioxidant and antimicrobial activities of essential oil of spearmint (mentha spicata L.) from Pakistan. Journal Essential Oil Research 2010, 22:78-84.

23. Kordali S, Cakir A, Mavi A, Kilic H, Yildirim A: Screening of chemical composition and antifungal and antioxidant activities of the essential oils from three Turkish Artemisia species. J Agric Food Chem 2005, 53:1408-1416.

doi:10.1186/1476-511X-11-167

Cite this article as: Hsouna and Hamdi: Phytochemical composition and antimicrobial activities of the essential oils and organic extracts from pelargonium graveolens growing in Tunisia. Lipids in Health and Disease 2012 11:167. 